Click chemistry revolutionised our ability to create custom proteins, so could it do the same for DNA? Professor Tom Brown at the University of Oxford and Professor Afaf El-Sagheer at Suez University are performing truly groundbreaking research into the application of 'click chemistry' bioconjugation techniques to DNA. Their technique allows the creation of DNA and RNA constructs larger than any other chemica flexible thant and is more This is malo possible by a This is made possible by a is biocompatible with DNAmanipulating cellular machinery in $\mathrm{E}$ coli and human cells.

very so often an observation, - experiment or discovery
- changes more than just scientific changes more than just scientific
derstanding. Darwin, Copernicus, and Newton's breakthroughs, while scientific, also had significance for philosophy, religion and metaphysics.

Perhaps Friedrich Wöhler's 1828 finding - that urea can be made from potassium cyanate and ammonium chloride - should also be included in this list. Urea, in his own words an 'animal substance', was the first to be created without any biological starting materials, signalling the end for the doctrine of vitalism.

In the decades since Wöhler, the list of biochemicals created using purely chemical means has grown longer, and the molecules themselves have grow early advancements include glucose

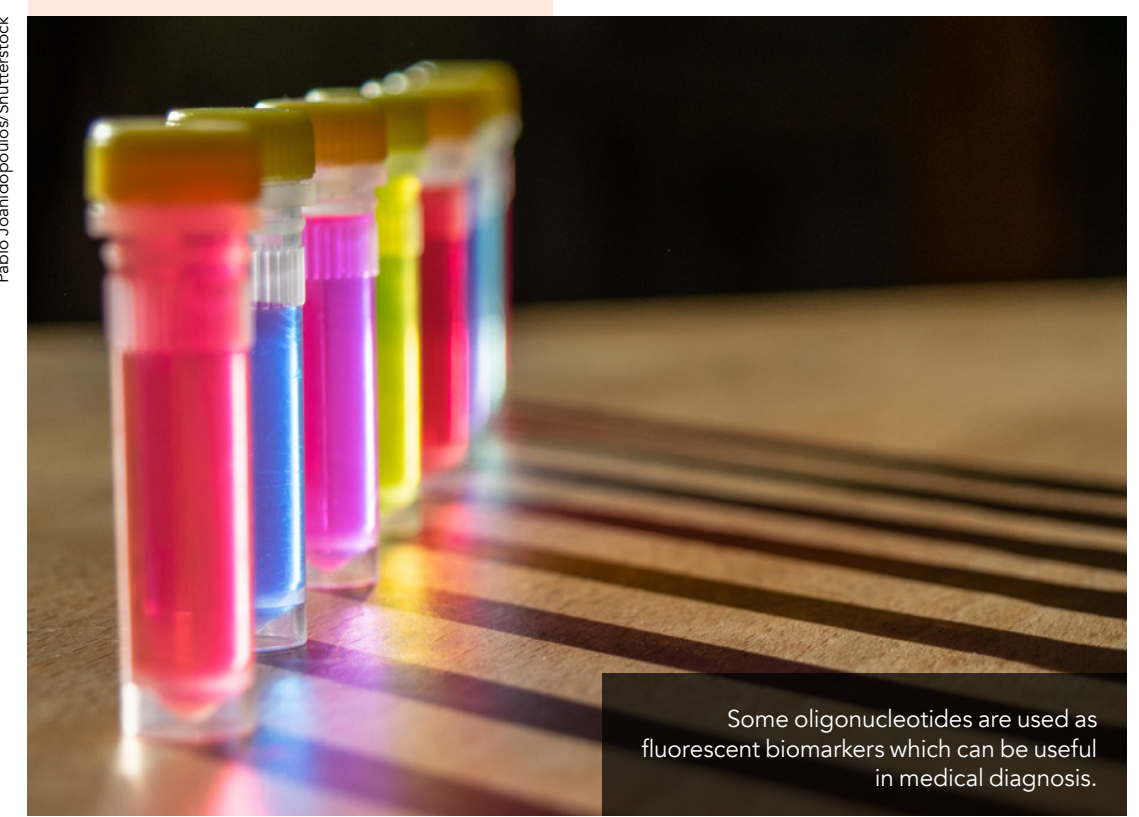

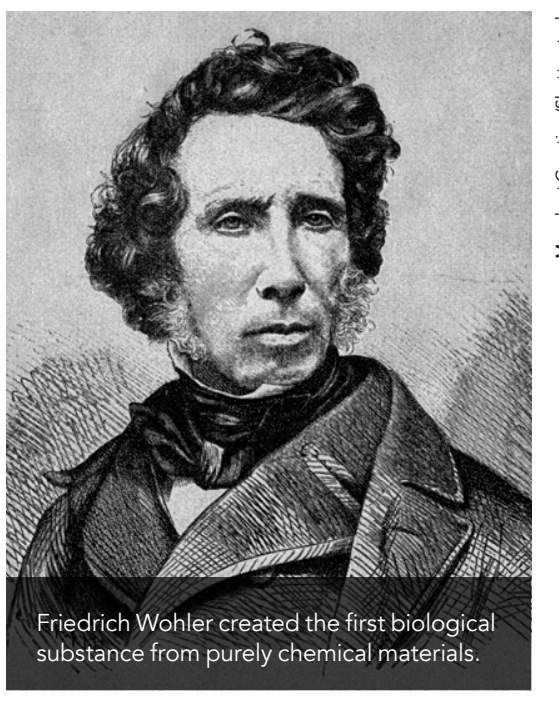

vitamin B12 and insulin; more recently larger molecules have become possible, including chemotherapies, antibiotics, and even proteins. But despite our progress, there is stilns Bu efective chemical synthesis of probably the most fano

The modern technique for constructing DNA sequences involves using biological enzymes to ligate (join together) short synthetic sections of DNA, called 'oligonucleotides' or 'oligos'. Multiple oligos can be assembled into genes and plasmids.

Oligos are almost always produced using the solid-phase phosphoramidite method. The error rate in this method is reasonably low - enough to create oligos typically around 100 bases long. However, at around the 150 bases mark, errors start to become a problem. As a result, long segments of DNA requi large numbers of oligos, requiring
complex biochemical techniques.

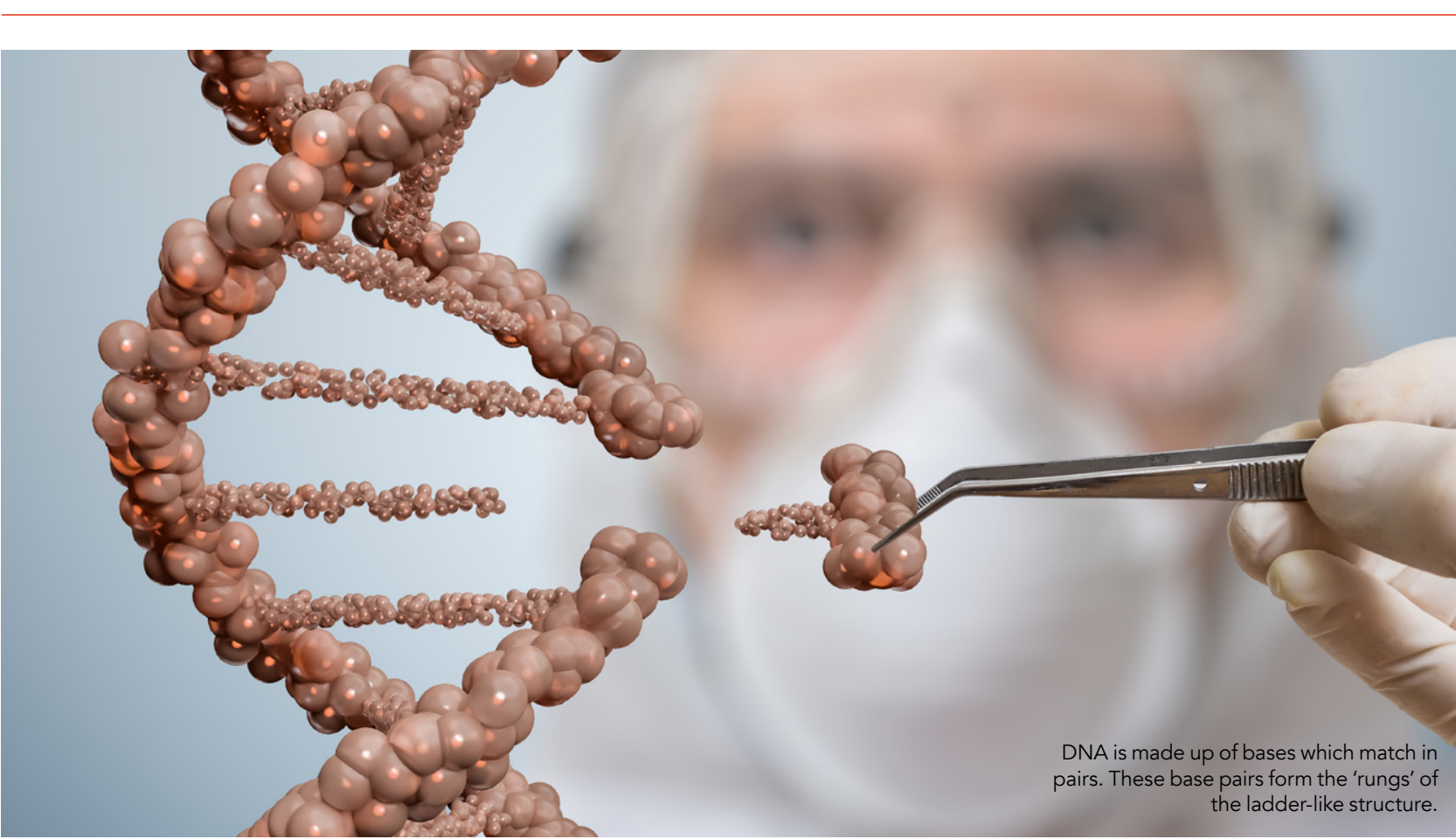

\section{CHEMICAL LIGATION}

Since 2007, Afaf ElSagheer and Tom Brown have been pioneering an alternative approach to the chemical synthesis of large DNA and RNA strands. Their premise is that longer oligos could be created from shorter oligos using chemical ligntic

But this is no mean feat: it's not possible for the chemical 'links' to be exact replicas of the phosphoester linkage found in natural DNA. Instead, the chemical links in these DNA replicas need to be 'biocompatble' - indistinguishable

Finding a chemical reaction which produces a biocompatible chemical linkage is a major milestone in El-Saghe and Brown's work. The researchers outline in their 2009 research how they use 'click chemistry', a set of chemica reactions known to efficiently form other molecules, a process known as bioconjugation

CuAAC

El-Sagheer and Brown began working on developing a variation of the 'copper(l)catalyzed azide-alkyne cycloaddition' (CuAAC) to tind a method which is suitable for ligating oligomers. CuAAC is the "lassic "lick chemistry reaction,
described as "the premier example of a

El-Sagheer and Brown's triazole linkage is a unique example of a biocompatible artificial DNA linkage formed using chemical synthesis. click reaction" by Sharpless, a pioneer of click chemistry techniques. CuAAC creates a triazole linkage - a fivemembered ring of atoms containing two carbon and three nitrogen atoms. Initiad experiments showed that it was possible to combine various oligomers using a version of CuAAC which joined two 'T"

These oligomers were then 'amplified' using PCR - the biochemical process PCR, the oligomer molecules containing the triazole linkage need to be 'read' by DNA polymerase, the key enzyme in the replication process. If the triazole linkage is biocompatible, then the PCR process should produce copies of the oligomer sequence. These resulting copies would not contain the triazole linkage.

\section{LIMITATIONS OF CUAAC}

However, this version of the CuAAC reaction had its limitations. While the DNA triazole linkage is read by DNA polymerase in $\mathrm{PCR}$, the process is slow, two nucleotides around the triazole. The
T-triazole-T sequence was converted to a single ' $T$ ' in the PCR product. In other words, the linkage is not a very good mimic of the phosphodiester linkage precursors on each end for the ligation step was difficult to accomplish.

Although one base was missing, the remarkable achievement was that the PCR process, for the first time successfully amplified triazole-linkcontaining oligomers.

\section{DEVELOPING BETTER LINKAGES} Sagheer and Brown began redesigning similar linkages, applying their technique

In 2010 work, they demonstrated that a redesigned triazole linkage could be used to synthesise nibozymes, which are a type of cellular machinery formed from RNA. RNA is a similar molecule to DNA of nany ways -its a polymer composed key differences which make long RNA 
chains even more difficult to synthesise than DNA. Cracially, RNA contains an can lead to unwanted side reactions unless it is protected during solid

phase synthesis and deprotection. This hydroxyl group is also a 'steric hindrance', meaning it physically gets in the way of molecules approaching the bond formation site.

As a result, RNA chains longer than 50 nucleotides are difficult to produce in a pure state, which doesn't com near to the length of biologically functional RNA constructs like ribozymes and riboswitches.

Using the CuAAC reaction, El-Sagheer and Brown were able to cross-link separate strands of oligomers toge almost 100 Rucleotides in length. Both the constructs a hairpin ribozym Bo with cross-links, and a hammerhead ribozyme with the improved linkage the active site - functioned like their natural equivalents.

After establishing the biocompatability of the new linkage in RNA in 2010 this improved linkage was used to ligate three 100-base-long oligomers to construct a DNA molecule of 300 bases in length, and amplified using PCR. Analysis of the resulting sequence confirmed the biocompatibility of the

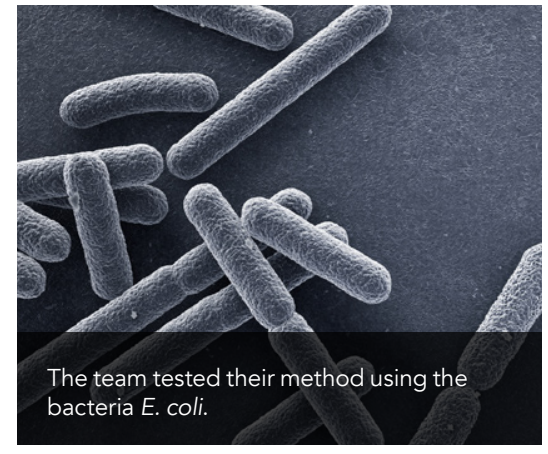

new triazole linkage: the DNA was accurately copied, whin nucleotides on both sides of the triazole linkage included in the oligomer copies.

\section{IN VIVO STUDIES}

is wever, the true test of biocompatibilly is within cells. In a crucial collaboration South were ligated using the CuAAC to form a triazo-containing piec of DNA known to code for antibiotic resistance, which was inserted into the DNA of E. colicells. Overnight incubation on agar plates containing ampicillin revealed exactly what the team was hoping for: the plates with the triazole DNA added contained $96.5 \%$ of the colonies; in the negative control it was only $1.6 \%$. In otherwords, E. colic cells given artificial DNA were shown to be resistant to the antibiotic E. E. coli cellular machinery.

200 years on from Wöhler's synthesis of urea, the enzyme-free synthesis of long DNA - or at least a functional mimic of it - is now possible.

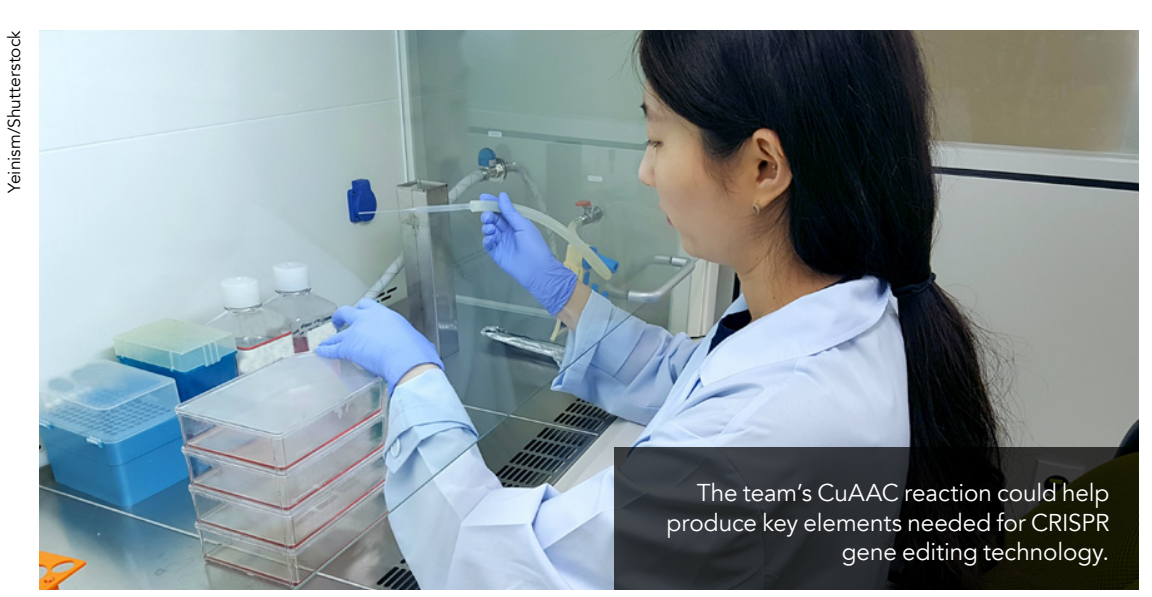

Repeating the test on E. colic cells that the success wasn't down to the linkage being 'corrected' by E. coli The link is truly biocompatible with DNAreading enzymes.

MEETING THE DEMANDS OF CRISPR

El-Sagheer and Brown's triazole linkage is a unique example of a biocompatible artificial DNA linkage formed using chemical synthesis. Almost 200 years on from Wöhler's synthesis of urea, the enzyme-free synthesis of DNA - or at least a functional mimic of it - is now possible, using click chemistry.

One area where the technique could excel is in the emerging and promising The technique relies on creating RNA sequences called single guide RNAs (sgRNAs). When CRISPR-Cas9 leaves the laboratory and enters diagnostic and therapeutic use, sgRNAs will be in high demand. But current use of enzymes to produce a library of sgRNAs is both time-consuming and difficult to scale.

These short sections of RNA are formed of two parts. Firstly, a section about 80 nucleotides long which binds to the Cas protein, and is the same in all sgRNA 20 nucleotides long which is unique to the sequence of DNA near where the edit should be made. This guides the Cas? protein to the corsect part of the

In their 2019 research published in Nature Communications, the group detailed how the CUAAC reaction can in a single tube - by ligating the two parts of sgRNA oligomers using click chemistry. The advantage of using this technique is that the Cas9-binding oligomer could be produced at a large scale, meaning only the 20-base oligomer needs to be tailored, and the two halves can be ligated.

The resulting sgRNA allowed gene editing in cells with no unexpected off-target effects. Perhaps CRISPR will be where the triazole linkage leaves its mark a simicent in DNA repair enzymes gave molecules. Secondly, a section about

\section{Behind the Research} 盛

Professor Afaf El-Sagheer

E: aff.el-sagheer@chem.ox.ac.uk T: +441865275175 E: tom.brown@chem.ox.acuk $\quad$ T: +44 1865275413 W: http:///www.browngroupnucleicacidsresearch.org.ukl

Research Objectives

Professors El-Sagheer and Brown investigate the chemical synthesis of long DNA and RNA strands.

\begin{tabular}{|c|c|c|c|}
\hline \multicolumn{4}{|l|}{ Detail } \\
\hline $\begin{array}{l}\text { Tom Brown } \\
\text { Department of Chemistry } \\
\text { University of Oxford } \\
\text { Chemistry Research Laboratory } \\
12 \text { Mansfield Road } \\
\text { Oxford OX1 3TA } \\
\text { UK } \\
\text { Afaf El-Sagheer } \\
\text { Department of Chemistry } \\
\text { University of Oxford } \\
\text { Chemistry Research Laboratory } \\
\text { 12 Mansfield Road } \\
\text { Oxford OX1 3TA } \\
\text { UK } \\
\text { and } \\
\text { Chemistry Branch } \\
\text { Department of Science and Mathematics } \\
\text { Faculty of Petroleum and Mining } \\
\text { Engineering } \\
\text { Suez University } \\
\text { Suez 43721 } \\
\text { Egypt }\end{array}$ & $\begin{array}{l}\text { Bio } \\
\text { Tom studied for } \\
\text { Bradford Univers } \\
\text { then Professor a } \\
\text { moving to South } \\
\text { Oxford Universit } \\
\text { Biotech compan } \\
\text { He has publishe } \\
\text { Afaf studied che } \\
\text { (Egypt) and did } \\
\text { with Professor Jc } \\
\text { Egypt to becom } \\
\text { to Associate Pro } \\
2014 \text { at Suez Un } \\
\text { sabbatical as an } \\
\text { and Oxford univ } \\
150 \text { publications } \\
\text { Afaf and Tom's r } \\
\text { oligonucleotide } \\
\text { chemistry, biolos } \\
\text { therapeutics). }\end{array}$ & $\begin{array}{l}\text { emistry degree and PhD at } \\
\text { was appointed as a Lecturer } \\
\text { uurgh University before } \\
\text { on University in } 1995 \text { then to } \\
113 . \text { He is co-founder of three } \\
\text { swel, Primer Design, ATDBio). } \\
400 \text { papers and patents. } \\
\text { at Suez Canal University } \\
\text { D at Southampton University } \\
\text { ellor then moved back to } \\
\text { turer. She was promoted } \\
\text { in } 2009 \text { then Professor in } \\
\text { x. Afa has been on a long } \\
\text { mic visitor at Southampton } \\
\text { s since } 2005 \text {. She has over } \\
\text { hinterests are in } \\
\text { sis and its applications in } \\
\text { medicine (diagnostics and }\end{array}$ & $\begin{array}{l}\text { Funding } \\
\text { Biotechnology and Biological } \\
\text { Sciences Research Council } \\
\text { (BB/J001694/2 and BB/ } \\
\text { R008655/1) } \\
\text { Collaborators } \\
\text { - Ali Tavassoli } \\
\text { - Pia Sanzone } \\
\text { - Lapatrada Taemaitree } \\
\text { - Arun Shivalingam } \\
\text { - Agnes Tyburn }\end{array}$ \\
\hline \multicolumn{2}{|l|}{ References } & \multicolumn{2}{|c|}{ Personal Response } \\
\hline \multicolumn{2}{|c|}{$\begin{array}{l}\text { Taemaitree, L., Shivalingam, A., El-Sagheer, A.H. and Brown, } \\
\text { T. (2019). Nat. Commun. 10, } 1610 . \\
\text { El-Sagheer, A.H. and Brown, T. (2017). Chem. Commun. 53, } \\
\text { 10700. } \\
\text { El-Sagheer, A.H. and Brown, T. (2012). Accounts of Chemical } \\
\text { Research. } 45 \text { (8), 1258-1267. } \\
\text { El-Sagheer, A.H. et al. (2011). PNAS. } 108 \text { (28), 11338-11343. } \\
\text { El-Sagheer, A.H. and Brown, T. (2010). PNAS. } 107 \text { (35), } \\
\text { 15329-15334. } \\
\text { El-Sagheer, A.H. and Brown, T. (2009). J. Am. Chem. Soc. }\end{array}$} & \multicolumn{2}{|c|}{$\begin{array}{l}\text { What would it take for this procedure to become a } \\
\text { commercially available product? } \\
\text { II The basic research has been carried out and patents } \\
\text { have been filed. The next step is for an industrial partner } \\
\text { to work on applications that could benefit from the } \\
\text { approach. This could be for example in CRISPR/Cas } \\
\text { but there are many other potential areas where click- } \\
\text { ligation could offer advantages, such as modified genes, } \\
\text { especially with epigenetic modification which can play a } \\
\text { vital role in gene therapy. }\end{array}$} \\
\hline
\end{tabular}

